\title{
A Correlation Between Intelligence Quotient, Emotional Quotient, And Adversity Quotient With Behavioral Problems In Adolescents
}

\author{
Rini Nahdarina ${ }^{\text {a, }}$, Nining Febriyana ${ }^{\text {b,* }}$, Atika $^{\mathrm{c}}$, Rachmad Suhanda $^{\mathrm{d}}$ \\ ${ }^{a}$ Medical Doctor, Specialist Medical Education Program for Psychiatrists/Functional Medical Staff of Psychiatry Sciences, Faculty of \\ Medicine, Universitas Airlangga/RSUD Dr. Soetomo Surabaya, Indonesia, rini.nahdarina@outlook.co.id \\ * Medical Doctor, Specialist Medical Education Program for Psychiatrists/Functional Medical Staff of Psychiatry Sciences, Faculty of \\ Medicine, Universitas Airlangga/RSUD Dr. Soetomo Surabaya, Indonesia, rini.nahdarina @ outlook.co.id \\ ${ }^{\mathrm{b}}$ Psychiatric consultant, Staff of Department/Functional Medical Staff of Psychiatry Sciences, Faculty of Medicine, Universitas \\ Airlangga/RSUD Dr. Soetomo Surabaya, Indonesia,dr_niningf@yahoo.com \\ *Psychiatric consultant, Staff of Department/Functional Medical Staff of Psychiatry Sciences, Faculty of Medicine, Universitas \\ Airlangga/RSUD Dr. Soetomo Surabaya, Indonesia,dr_niningf@yahoo.com \\ 'Department of Public Health-Preventive Medicine, Faculty of Medicine, Universitas Airlangga, Indonesia, atika.ikmkp@gmail.com \\ ${ }^{\mathrm{d}}$ Department of Public Health and Community Medicine, Faculty of Medicine, Universitas Syiah Kuala, Indonesia, \\ rachmadsuhanda@unsyiah.ac.id
}

\begin{abstract}
Background: Adolescents both low intellectual and emotional intelligence, will have a high risk of undergoing behavioral problems. The number of studies related to the correlation between intelligence (IQ and EQ) and behavioral problems is still categorized as limited. Even, to date, there is no study discussing one of the intelligence types, namely AQ, and behavioral problems in adolescents. This study aimed at analyzing the relationship of IQ, EQ, and AQ with adolescents' behavior at Marsudi Putra Social House, Surabaya.

Method: This study was conducted at Marsudi Putra Technical Implementation Unit of Social Protection and Rehabilitation, Surabaya, from January 2020 to May 2021. The research design was cross-sectional design by involving 60 adolescents as the sample. The instruments were a demographic characteristic questionnaire, an SDQ questionnaire, an IQ questionnaire, an EQ questionnaire, and an AQ questionnaire.

Result: The majority of the adolescents had a normal IQ level with an average total of EQ score of $130.78 \pm 19.41$, and no adolescent was found to have a low AQ score. The behavioral problem frequently experienced by the respondents was borderline (most adolescents had a behavioral problem to be managed correctly).

Conclusion: This study shows that there is no correlation between IQ and AQ with the adolescents' behavioral problems at Marsudi Putra Technical Implementation Unit of Social Protection and Rehabilitation, Surabaya. However, the adolescent behavioral problems are influenced by the adolescents' EQ.
\end{abstract}

Keywords: Intelligence quotient, emotional quotient, adversity quotient, behavioral problems

\section{Background}

The adolescence phase with distinct physiological changes, social environment, and the increase in autonomy (Jaworska and MacQueen, 2015). Adolescents need to be motivated to have a chance to be independent and responsible for their deeds to reach the process of maturity (Pomerantz et al., 2011). The proportion of suboptimal behaviors in adolescents based on the studies that had been conducted is quite high. Based on the Basic Health Research in 2013, in Indonesia, the proportion for behavioral problems, such as smoking and alcohol consumption, is around $1.4-18.3 \%$ in adolescents aged 10-19 years old (Indonesian Ministry of Health, 2013). The prevalence was increased, based on Basic Health Research in 2018; it is shown by the prevalence of smoking in adolescents was $9.1 \%$ (according to Basic Health Research in 2013, it increased from 7.2\% and $8.8 \%$ based on the National Health Indicator Survey in 2016) (Indonesian Ministry of Health, 2018). Based on 
information released by the National Narcotics Agency states that the proportion of drug abuse among students in 2018 (from 13 provincial capitals in Indonesia) reached 2.29 million people. One of the community groups prone to be exposed to drug abuse is those in the age range of 15-35 years old. Adolescent behavioral problems definitely and negatively affect the life quality of adolescents, parents, and their environment (Spilková \& Dzúrová, 2012; Li et al., 2017). Adolescence can cause suffering and disabilities, as well as lower academic achievement in school activities and much lower educational level in adolescents with behavioral problems (McLeod, Uemura, \& Rohman, 2012).

Several studies showed the correlation between intelligence and behavioral problems. Adolescents with low intellectual intelligence will tend to have adolescent behavioral problems. Besides intellectual intelligence, emotional intelligence is also correlated with adolescent behavioral problems, whereby a lower intelligence is correlated with an adolescent's vulnerability to experiencing behavioral problems (Koohsar and Bonab, 2011). Nevertheless, the number of studies related to this topic is still limited, and this topic has never been conducted in Indonesia. The number of studies investigating the correlation between adversity quotient (AQ) or adversity intelligence and behavioral problems is still limited. A study related to AQ has ever been conducted by Siphai (2015) in Thailand with the result stating that adversity quotient (AQ) and moral quotient had a direct and positive impact on good citizenship activities.

In this study, an analysis regarding the correlation between intelligence and adolescent behavioral problems was conducted. Specifically, this study aimed at analyzing the correlation of IQ, EQ, and AQ with adolescent behavioral problems at a Social House called Marsudi Putra Technical Implementation Unit of Social Protection and Rehabilitation, Surabaya.

\section{Method}

The study used an observational analytical approach with a cross-sectional design. The study was conducted at a Social House called Marsudi Putra Technical Implementation Unit of Social Protection and Rehabilitation located in Surabaya, East Java. The data collection of research samples was conducted in December 2020. The time for the entire study was started from January 2020 to June 2021. The population was adolescents aged around 12-19 years old at a Social House of Marsudi Putra Technical Implementation Unit of Social Protection and Rehabilitation, Surabaya. The sampling method was done using the total sampling technique in the study site in December 2020.

The inclusion criteria were adolescents enrolled in December 2020 at the Social House, aged around 10-19 years old, able to speak Indonesian both orally and written, and willing to sign the informed consent, while the exclusion criterion was adolescents with mental retardation. The independent variables were IQ (Intelligence Quotient), EQ (Emotional Quotient), and AQ (Adversity Quotient), while the dependent variable was adolescent behavioral problems. The validity test of research instruments was conducted in 20 adolescents before collecting the data with a valid and reliable result. The result analysis for the correlation between intelligence and adolescent behavioral problems was tested using Spearman's rank correlation coefficient. The ethical clearance was acquired from the Ethical Committee of the Faculty of Medicine, Universitas Airlangga.

\section{Result}

The respondents' characteristics in this study had 60 people as the sample. The type of respondents was divided into two, namely 12 Children in Conflict with the Law (CICL) and 48 regular respondents. 
Table 1. The Respondents' Characteristics at a Social House of Marsudi Putra Technical Implementation Unit of Social Protection and Rehabilitation, Surabaya in $2020(n=60)$

\begin{tabular}{|c|c|c|c|}
\hline \multirow{2}{*}{ Characteristics } & \multicolumn{2}{|c|}{ Types } & \multirow{2}{*}{ Total } \\
\hline & CICL $(n=12)$ & Regular $(n=48)$ & \\
\hline \multicolumn{4}{|l|}{ Age } \\
\hline Mean Score \pm Standard Deviation & $16.50 \pm 1.00$ & $16.81 \pm 1.07$ & $16.75 \pm 1.05$ \\
\hline \multicolumn{4}{|l|}{$\operatorname{Sex}[\mathrm{n}(\%)]$} \\
\hline Male & $12(100 \%)$ & $48(100 \%)$ & $60(100 \%)$ \\
\hline Female & $0(0 \%)$ & $0(0 \%)$ & $0(0 \%)$ \\
\hline Islam & $12(100 \%)$ & $48(100 \%)$ & $60(100 \%)$ \\
\hline \multicolumn{4}{|l|}{ Marital Status [n (\%)] } \\
\hline Single & $12(100 \%)$ & $48(100 \%)$ & $60(100 \%)$ \\
\hline \multicolumn{4}{|l|}{ Ethnicity [n (\%)] } \\
\hline Javanese & $11(91.7 \%)$ & $48(100 \%)$ & $59(98.3 \%)$ \\
\hline Madurese & $1(8.3 \%)$ & $0(0 \%)$ & $1(1.7 \%)$ \\
\hline Senior High & $3(25 \%)$ & $2(4.2 \%)$ & $5(8.3 \%)$ \\
\hline \multicolumn{4}{|l|}{ Living with... [n (\%)] } \\
\hline Father & $0(0 \%)$ & $4(8.3 \%)$ & $4(6.7 \%)$ \\
\hline Mother & $5(41.7 \%)$ & $6(12.5 \%)$ & $11(18.3 \%)$ \\
\hline Parents & $6(50 \%)$ & $30(62.5 \%)$ & $36(60 \%)$ \\
\hline Another family member & $1(8.3 \%)$ & $8(16.7 \%)$ & $9(15 \%)$ \\
\hline
\end{tabular}

The age range of age range was 15-19 years with an average of 16.75 years old with the similar characteristic for sex, religion, and marital status. The majority of the respondents' ethnic background was Javanese (98.3\%) and only one CICL respondent was Madurese (1.7\%). The majority of the respondents' last education was Junior High. Most of the adolescents lived with their parents $(60 \%)$.

Table 2. The Characteristic Distribution by the Descriptive Numerical Scores of IQ, EQ, and AQ at a Social House of Marsudi Putra Technical Implementation Unit of Social Protection and Rehabilitation, Surabaya in $2020(\mathrm{n}=60)$

\begin{tabular}{lccc}
\multicolumn{1}{c}{ Characteristics } & \multicolumn{3}{c}{ Types } \\
\cline { 2 - 4 } & CICL $(\mathrm{n}=12)$ & Regular $(\mathrm{n}=48)$ \\
\hline IQ Score & & & \\
Mean Score \pm Standard Deviation & $89.25 \pm 9.30$ & $91,85 \pm 8,57$ & $91,33 \pm 8,70$ \\
Median (min - max) & $91(70-105)$ & $92(76-118)$ & $92(70-118)$ \\
\hline Total EQ Score & $119,75 \pm 21,24$ & $133,54 \pm 18,12$ & $130,78 \pm 19,41$ \\
$\quad$ Mean Score \pm Standard Deviation & $114,50(97-166)$ & $133,50(88-167)$ & $130(88-167)$ \\
Median (min - max) & & & \\
Total AQ Score & $93,83 \pm 9,48$ & $97,65 \pm 9,31$ & $96,88 \pm 9,39$ \\
Mean Score \pm Standard Deviation & $91,50(78-110)$ & $98,50(76-118)$ & $98(76-118)$ \\
Median (min - max) & & &
\end{tabular}

The total score range of adolescents' IQ was 70-118 points with median of 92 . The average total score of adolescents' EQ, from both CICL and regular groups, was $130.78 \pm 19.41$. The group of regular adolescents had a higher average total EQ score than the CICL adolescent group. The total AQ score range of adolescents, from both CICL and regular groups, was around 76-118 points with a median of 98 points. The group of regular adolescents also had a higher median score for IQ score and total AQ score than the group of CICL adolescents. 
Table 3. The Respondents' Characteristic Distribution by the Level of IQ, Degree of EQ, and Level of AQ at a Social House of Marsudi Putra Technical Implementation Unit of Social Protection and Rehabilitation, Surabaya in $2020(n=60)$

\begin{tabular}{|c|c|c|c|}
\hline \multirow{2}{*}{ Characteristics } & \multicolumn{2}{|c|}{ Types } & \multirow{2}{*}{ Total } \\
\hline & $\operatorname{CICL}(n=12)$ & Regular $(n=48)$ & \\
\hline \multicolumn{4}{|l|}{ Level of IQ [n (\%)] } \\
\hline Borderline & $2(16.7 \%)$ & $5(10.4 \%)$ & $7(11.7 \%)$ \\
\hline Normal & $7(58.3 \%)$ & $28(58.3 \%)$ & $35(58.3 \%)$ \\
\hline High average & $0(0 \%)$ & $1(2.1 \%)$ & $1(1.7 \%)$ \\
\hline \multicolumn{4}{|l|}{ Degree of EQ } \\
\hline High & $2(16.7 \%)$ & $19(39.6 \%)$ & $21(35.0 \%)$ \\
\hline \multicolumn{4}{|l|}{ Level of AQ [n (\%)] } \\
\hline Moderate & $9(75.0 \%)$ & $35(72.9 \%)$ & $44(73.3 \%)$ \\
\hline High & $3(25.0 \%)$ & $13(27.1 \%)$ & $16(26.7 \%)$ \\
\hline
\end{tabular}

The majority of the respondents' level of IQ was normal of 35 people (58.3\%), while the least was one regular adolescent $(1.7 \%)$ in the high average. Moreover, there were some adolescents with a level of IQ categorized as borderline and average. The percentage of the adolescents' level of AQ categorized as moderate $(73.3 \%)$ was higher than those with a level of AQ categorized as high (26.7\%). The characteristic distribution of SDQ (Strenght and Difficulties Questionnaire) score as the score of behavioral problems is as follows:

Table 4. The Characteristic Distribution by the Descriptive Numerical Score of SDQ at a Social House of Marsudi Putra Technical Implementation Unit of Social Protection and Rehabilitation, Surabaya in $2020(n=60)$

\begin{tabular}{lccc}
\multicolumn{1}{c}{ Total SDQ Score } & \multicolumn{3}{c}{ Types } \\
\cline { 2 - 4 } & CICL $(\mathrm{n}=12)$ & Regular $(\mathrm{n}=48)$ \\
\hline Mean Score \pm Standard Deviation & $20.67 \pm 6.10$ & $27.04 \pm 7.24$ & $25.77 \pm 7.43$ \\
Median $(\min -\max )$ & $21.50(11-30)$ & $27.50(11-38)$ & $26(11-38)$ \\
\hline
\end{tabular}

The total score range of adolescents' SDQ, from both CICL and regular groups, was 11-38 points with a median of 21.5 points in the CICL group and 27.5 points in the regular group. The mean score of the regular group was higher than that of the CICL group.

Table 5. The Characteristic Distribution by the Descriptive Numerical Score of SDQ at a Social House of Marsudi Putra Technical Implementation Unit of Social Protection and Rehabilitation, Surabaya in $2020(n=60)$

\begin{tabular}{|c|c|c|c|}
\hline \multirow{2}{*}{ Characteristics } & \multicolumn{2}{|c|}{ Types } & \multirow{2}{*}{ Total } \\
\hline & $\operatorname{CICL}(\mathrm{n}=12)$ & Regular $(n=48)$ & \\
\hline \multicolumn{4}{|l|}{ Behavioral Problems } \\
\hline Abnormal & $4(33,3 \%)$ & $4(8,3 \%)$ & $8(13,3 \%)$ \\
\hline Normal & $0(0 \%)$ & $11(22,9 \%)$ & $11(18,3 \%)$ \\
\hline
\end{tabular}

The analysis of SDQ from 60 adolescents as the research respondents obtained a result that the dominant adolescent behavioral problem was borderline, followed by normal and abnormal. The analysis of the correlation between IQ and behavioral problems in adolescents as the research respondents using the Spearman's Rank Correlation Coefficient is presented in the following table.

Table 6. The Correlation of Levels of IQ, EQ scores, and levels of AQ with Behavioral Problems at a Social House of Marsudi Putra Technical Implementation Unit of Social Protection and Rehabilitation, Surabaya in $2020(n=60)$

\begin{tabular}{lccc}
\multicolumn{1}{c}{ Correlation } & $\mathrm{n}$ & Spearman's Rank Correlation Coefficient $\left(\mathrm{r}_{\mathrm{s}}\right)$ & P-value \\
\hline Level of IQ with SDQ Score & 60 & 0,044 & 0,674 \\
Degree of EQ with SDQ Score & 60 & 0,298 & 0,021 \\
Level of AQ with SDQ Score & 60 & 0,078 & 0,552 \\
\hline
\end{tabular}


The result of the Spearman's Rank Correlation Coefficient showed no significant correlation between levels of IQ and behavioral problems with a total SDQ score ( $p>0.05)$. The result of the Pearson's correlation test showed that there was a significant correlation between the total EQ score and behavioral problems with a positive and weak correlation. The result of the Spearman's Rank Correlation Coefficient showed no significant correlation between levels of AQ and behavioral problems with a total SDQ score $(\mathrm{p}>0.05)$.

\section{Discussion}

Around more than a half of the number of male adolescents at a Social House of Marsudi Putra Technical Implementation Unit of Social Protection and Rehabilitation, Surabaya, as the research sample had a level of IQ categorized as normal. The adolescents' intellectual intelligence measured by the level of IQ (Intelligence Quotient) had no significant correlation with behavioral problems measured by the total SDQ (Strengths and Difficulties Questionnaire) score.

The result of a study conducted by Hartini (2017) in SMPN 1 Kadugede, Kuningan Regency, found that IQ affected the social behavior of adolescent students. Intellectual intelligence had a positive and significant influence; the higher the intellectual intelligence, the better the adolescents' behavior. The correlation between IQ and social behavior showed a strong correlation. It is not in line with the result of a study conducted at Marsudi Putra Technical Implementation Unit, Surabaya. This condition was supposed to happen because the children in the social house had a different characteristic from other children in the control study.

The result of this study is also not in line with a study conducted by Aziz dan Mangestuti (2006) stating that intellectual, emotional, and spiritual intelligence simultaneously affected the aggressivity in the students of Universitas Islam Negeri, Malang. The difference between the results of those studies was because the sample of the study was university students, not adolescents.

Behavioral problems in male adolescents at a Social House of Marsudi Putra Technical Implementation Unit of Social Protection and Rehabilitation, Surabaya, were not affected by intellectual intelligence measured by levels of IQ. The behavioral problems in adolescents, based on the result of the study, were not significantly influenced by intellectual intelligence, dominantly considered as "innate capacity"; however, they were influenced more by environmental factors starting from family. The environmental factors are several experiences perceived by adolescents, namely child neglect dan abuse, failures at school, and traumatic life experience.

It can happen because most behavioral problems are influenced by the capability in managing emotional intelligence in adolescents. Adolescence is a phase of emotional development. This emotional development in adolescence tends to be higher than during childhood because most adolescents live under higher social pressure and deal with new conditions. The stimulus exciting emotions in adolescents is higher than in children (Fatmawaty, 2017). Environmental factors are considered important to be reviewed further to be able to explain the phenomenon.

According to Baker (2016), environmental factors are, instead, the most important factor in triggering behavioral problems because these factors are systematic and long-term. The poverty condition, the environment of being addicted to substances, especially alcohol, depressed mothers, relatives with behavioral disorders, and the exposure to violence and aggressivity via media are examples of the environmental factors. Several things experienced by adolescents will be a part of their decision-making, for instance, experience, ignorance, failures, and traumatic events.

The adolescents' emotional intelligence measured by the total EQ (Emotional Quotient) score had a significant correlation with behavioral problems with a positive and weak correlation. The correlation shows that the higher the total EQ score of an adolescent, the higher their total SDQ (Strengths and Difficulties 
Questionnaire) score. The total SDQ score becomes a measuring instrument for behavioral problems in adolescents.

A stimulus that excites emotions in adolescents tends to be higher than other age groups (Fatmawaty, 2017). Emotional intelligence is a person's capability in perceiving, understanding, and controlling oneself and other people. An adolescent with a good EQ will be able to lead his/her thoughts and emotions in the correct direction and influence someone's performance. EQ can develop through experience and then stop at a certain age. So, someone's EQ that develops very well can lead his/herself to behave well and influence other people.

The result of this study is in line with a study conducted by Husada (2013) stating that emotional intelligence significantly affects prosocial behavior in adolescents. Children with a good emotional intelligence who live in a family with a democratic parenting style can improve the children's prosocial behavior, such as sharing, collaborating, donating, helping, and paying attention to other people's well-being. The rest is influenced by other factors, such as the school environment and condition (Husada, 2013).

Another study supporting the result of this study was conducted in Bengkulu city showed that emotional intelligence in students grade X of Mechanical Engineering class in SMKN 2 has a strong negative correlation with aggressive behavior. The correlation shows that the higher the level of emotional intelligence in a student, the aggressive behavior is decreasing. The study with 50 students as the sample measures the aggressive behavior through several items, namely physical aggressive, verbally aggressive, attacking a certain object, and violating other people's property (Herawati et al., 2017).

One of the items in the SDQ is hyperactivity. Two types of hyperactive behavior or hyperactivity according to Grainger (2003) are oppositional defiant disorder and attention deficit hyperactive disorder. The oppositional defiant disorder is like aggressive behavior, disobedience, destruction, anger, and lies. Therefore, the adolescents' aggressive behavior is one of the hyperactive behaviors that is mostly shown by adolescents with low emotional intelligence. The classification of hyperactivity in the SDQ in male adolescents at a Social House of Marsudi Putra Technical Implementation Unit of Social Protection and Rehabilitation, Surabaya, is mostly abnormal compared to normal and borderline. Nevertheless, the total SDQ score is also determined by the other four assessment items, namely prosocial, emotional problems, behavioral problems, and problems regarding peer relationships.

A study conducted by Hartini (2017) found that EQ significantly affected the students' social behavior. The impacts of EQ on social behavior are positive; the better the emotional intelligence, the behavior is getting better. This significance proves that the impacts of emotional intelligence are positive. Emotional intelligence is also translated as a capability to recognize good feelings on an individual or other people. The condition will allow the adolescents to have good interaction with other people. Emotional intelligence with a high EQ score in male adolescents at a Social House of Marsudi Putra Technical Implementation Unit of Social Protection and Rehabilitation, Surabaya, enables them to minimize behavioral disorders.

The level of AQ (Adversity Quotient) had no significant correlation with behavioral problems that were measured by the total SDQ (Strengths and Difficulties Questionnaire) score. AQ is a measurement for identifying someone's struggle to be able to deal with adversities and self-confidence in controlling his/her life and the ability to solve the challenges and obstacles they face in achieving success (Hidayati and Farid, 2016).

The male adolescents at a Social House of Marsudi Putra Technical Implementation Unit of Social Protection and Rehabilitation, Surabaya, experienced behavioral problems measured by the total SDQ score, but they did not correlate with their level of AQ. The SDQ has 5 measurement items, namely prosocial, emotional problems, behavioral problems, hyperactivity, and problems regarding peer relationships.

Citing the statement by Holman and Silver that people with high durability are those who do not experience many difficult situations in their life. If it is correlated with the result of the study obtaining that all children are categorized in the borderline and normal criteria, so the adolescents as the research sample tend to interpret their life as easy situation or deny their difficult conditions. Even though most adolescents dominantly experience 
behavioral problems, it is not in line with a study obtaining that there is no adolescent with abnormal AQ. The adolescents' endurance and durability seem to be acquired from a wrong environment; forming a high endurance and durability but it can stimulate them to perform wrongdoings. This condition explains the reason why children's AQ tend to be good, but behavioral problems are also dominantly found.

The result of this study is relevant to a study conducted by Hidayati and Farid (2016) revealing that AQ does not correlate with the adolescents' self-adaptation. Another relevant study was conducted by Budiani, et al., (2014) stating that AQ and emotional intelligence simultaneously do not affect the Junior High teachers' professional behavior in Buleleng sub-district, Buleleng Regency.

It can conclude that adolescence is a defining period in structuring life. The behavioral problems in male adolescents at a Social House of Marsudi Putra Technical Implementation Unit of Social Protection and Rehabilitation, Surabaya, were correlated with emotional intelligence (EQ), not levels of intellectual intelligence (IQ) and levels of AQ. Life experience can increase the risk of cognitive problems, physical and social health problems resulting in problematic behaviors (Fahiroh, 2019). The tendency to behave/do unpleasant deeds that are physically and psychically dangerous may happen (Saputra \& Handaka, 2018). The adolescents' motivation in seeking the life pattern will stimulate them to pleasantly do or try to share activities. The activities that have been done without a good direction will cause problems, harm, or disturb other people (Sumara, Humaedi, \& Santoso, 2017).

\section{Conclusion}

The majority of the adolescents' level of IQ is normal and the least is one regular adolescent in the high average. The group of regular adolescents has a higher total average EQ score than that of the group of CICL adolescents. Most of the adolescents' level of AQ is moderate compared to high and no adolescent is found to have a low level of AQ. The adolescents' dominant behavioral problem is borderline, indicating that most adolescents have behavioral problems that need to be managed well. Only 11 out of 60 adolescents are categorized as normal.

Intellectual intelligence measured by the level of IQ has no significant correlation with behavioral problems. Emotional intelligence measured by the total EQ score has a significant correlation with behavioral problems with a positive and low or weak correlation in adolescents. The level of AQ has no significant correlation with behavioral problems.

The next studies can include the internal and environmental factors to obtain a more optimal result in studying the behavior in adolescents, including the study on moral quotient. The duration for the approach in the correlation between the researcher and the respondents needs to be increased. More attention from the social house's manager is needed to correctly manage the big proportion of adolescent behavioral problems found in this study.

\section{Acknowledgements}

The Specialist Medical Education Program for Psychiatrists and all the Functional Medical Staff of Psychiatry Sciences, Faculty of Medicine, Universitas Airlangga/RSUD Dr. Soetomo Surabaya.

\section{References}

Aziz, R. dan Mangestuti, R. 2006 .Pengaruh kecerdasan intelektual (IQ), kecerdasan emosional (EI), dan kecerdasan spiritual (SI) terhadap agresivitas mahasiswa UIN Malang. El-Qudwah, Jurnal Penelitian dan Pengembangan, Vol .1, No. 1, April 2006. 
Baker, K. 2016. Conduct disorders in children and adolescents. Paediatrics and Child Health (United Kingdom) 26(12):534-539.

Budiani, I. A. P., Dantes, N., Dantes, K.R. 2014. Determinasi kecerdasan emosional dan adversity quotient terhadap sikap profesional ditinjau dari status profesi guru di Kecamatan Buleleng, Kabupaten Buleleng. e-Journal Program Pascasarjana Universitas Pendidikan Ganesha, Program Studi Pendidikan Dasar Vol. 4, 2014.

Fahiroh, SA. 2018. Resiliensi Keluarga Mencegah Perilaku Bermasalah Pada Anak dan Remaja. In: Proceeding National Conference Psikologi UMG.

Fatmawaty, R. 2017. Memahami psikologi remaja. Jurnal Reforma 2017, Vol. 6, No. 02.

Grainger, J. 2003. Children's Behaviour, Attention, and Reading Problems. Terjemahan. Jakarta : Gramedia.

Hartini, T. 2017. Pengaruh kecerdasan intelektual (IQ), kecerdasan emosional (EQ) dan kecerdasan spiritual (SQ) terhadap peri laku sosial siswa SMPN 1 Kadugede Kabupaten Kuningan. OASIS : Jurnal Ilmiah Kajian Islam Vol.1, No. 2, Februari 2017 : 1-16.

Herawati, A. A., Dharmayana, I. W., Sholihah, A. 2017. Kecerdasan emosional dan perilaku agresif siswa vokasi. TRIADIK Vol. 16, No. 1, April 2017: 84-91

Hidayati, K. B. dan Farid, M. 2016. Konsep diri, adversity quotient dan penyesuaian diri pada remaja. Persona, Jurnal Psikologi Indonesia 2016, Vol. 5, No. 2, 137-144.

Husada, A. K. 2013. Hubungan pola asuh demokratis dan kecerdasan emosional dengan perilaku prososial pada remaja. Persona, Jurnal Psikologi Indonesia 2013, Vol. 2, No. 3, 266-277.

Indonesian Ministry of Health. 2013. Laporan Nasional RISKESDAS. Jakarta: Lembaga Penerbit Badan Penelitian dan Pengembangan Kesehatan (LPB).

Indonesian Ministry of Health. 2018. Laporan Nasional RISKESDAS. Jakarta: Lembaga Penerbit Badan Penelitian dan Pengembangan Kesehatan (LPB).

Jaworska, N., \& MacQueen, G. 2015. Adolescence as a unique developmental period. Journal of Psychiatry and Neuroscience 40(5):291293.

Koohsar, A. A. H. \& Bonab, B. G. 2011. Relation between quality of attachment and life satisfaction in high school administrators. Procedia - Social and Behavioral Sciences, 30, pp. 954-958.

McLeod, J. D., Uemura, R. \& Rohman, S. 2012. Adolescent Mental Health, Behavior Problems, and Academic Achievement. Journal of Health and Social Behavior, 53(4), pp. 482-497.

Pomerantz, E. M., Qin, L., Wang, Q., \& Chen, H. 2011. Changes in Early Adolescents' Sense of Responsibility to Their Parents in the United States and China: Implications fo Academic Functioning. Child Development, 82(4) pp. 1136-1151.

Saputra, WNE., \& Handaka IB. 2018. Perilaku Agresi Pada Siswa SMK di Yogyakarta. Jurnal Fokus Konseling 4(1):1-8.

Siphai, S. 2015. Influences of moral, emotional and adversity quotient on good citizenship of Rajabhat University's Students in the Northeast of Thailand, Educational Research and Reviews, 10(17), pp. 2413-2421. 